\title{
A Prelude to Material Hermeneutics (2021)
}

\section{Don Ihde}

Stony Brook University

515 79th St, Apt. 14A

New York NY 10075, USA

Email: don.ihde@stonybrook.edu

\begin{abstract}
This paper, originally given in Groningen, the Netherlands, proposed a 'material hermeneutics', or, metaphorically, an interpretation which "lets things speak" via new scientific imaging technologies. Such a material hermeneutics would add to, perhaps often displace the usual linguistictextual hermeneutics so refined by Paul Ricœur. I outline several examples of such a hermeneutics here based on some 40 or more years of technoscience experience.
\end{abstract}

Keywords: big science, humanities, imaging technologies, material hermeneutics, Paul Ricœur

This paper is dedicated to the 100th anniversary of Paul Ricour's birth. My first book, Hermeneutic Phenomenology: The Philosophy of Paul Ricour (1971) was an analysis of his work up to 1968, and my 1964 dissertation was the first English language dissertation on his work. The book was drafted while in Paris in 1967-1968, eventful years which will never be forgotten. I want to mention a few things about those years to illustrate what a genuine gentleman and generous person Ricœur was. My first personal meeting with him was in 1963 when I first decided upon my dissertation theme. He presented a talk, one of his first in English, at one of Erwin Strauss's Pure and Applied Phenomenology Conferences at the Veterans Hospital in Lexington, Kentucky. I didn't know whether to be impressed or not, since Ricœur's English at that point was so accented that he was impossible to understand. Later, with his recommendation, I won a Fulbright Research Fellowship to France-for 1967-1968. That year I was able to attend all his various lectures, at Nanterre, at the Institut Catholique, at a special seminar

Lecture given in Groningen, 2013, on the occasion of Paul Ricœur's 100th birthday. 
in the basement of the Sorbonne. My spoken French was quite weak, but we exchanged dinners; had fierce arguments about the gold standard; and then at the end of my stay, he insisted that we move into his apartment in ChâtenayMalabry in the Esprit compound-which we did and this then gave me access to the very manuscripts he was working on in 1968.

Our paths crossed with some frequency over the years-in part because once one has done a book on someone else, one's fate is to be repeatedly invited to continue responses and interpretations upon that individual. There are many tales, in Warwick his discovery that the French lost the battle of Warwick which was left blank in French history, subsequently in Canada, the US and France we shared conferences. His life was filled with tragic events: the destruction of his vast library by the German invaders wishing to destroy French culture; his years during World War II in a prisoner-of-war camp where he and Mikel Dufrenne set up a prison university, tragedies concerning two of his children and a son-inlaw, and the death of his wife well before he, himself, died at 92. He was never to plead the victim; he was constantly generous; and although several times viciously attacked, as by the Lacanians on his Freud work and by the students during the events of May 1968, he remained calm and rational.

And now, finally, before turning to my topic, I need to make a small confession: The early 1960s were just at that point when phenomenology was beginning to become visible in North America. William Richardson published the first English language systematic work on Martin Heidegger, Through Phenomenology to Thought (1962), and at one of the first meetings of the Society for Phenomenology and Existential Philosophy, presented its major conclusions. It became apparent to me from that session to a whole series of subsequent sessions that Richardson was being perceived as "Mr. Heidegger" or at least the spokesman for Heidegger interpretation, and I remember I distinctly thought to myself, "I do not want such a fate or role as a philosopher", and so I became wary of too many Ricœur interpretation sessions, although some were unavoidable. This will set the tone here as well — with utmost respect for Ricœur as a person and a philosopher, the times and the theme of this conference point in directions post-Ricœur. The call for papers both recognized that Ricœur had, like so many Anglo-American and continental hermeneutics philosophers, made a linguistic turn. In Ricœur's case, his emphasis upon narrative and the world of the text became his signature.

Yet, as the call for papers also recognized, "in the last decades, the vast expansion of new media [...] is rapidly changing the landscape of the humanities, making it entirely different from the text-oriented culture in which Ricœur was working." 
It is precisely in recognizing this shift which overcomes or even reverses the linguistic turn, that what I call material hermeneutics has begun to take shape. Here, then, I shall present an initial outline of such a hermeneutics whose tools are primarily those of new imaging technologies. My Expanding Hermeneutics: Visualism in Science (1998) presented an outline of a deliberate program of material hermeneutics whose origins I see in the visual hermeneutics already practiced in the natural sciences.

With broad brush strokes, this is what I think is happening: I contend that the sciences are currently in the midst of a second scientific revolution related to the explosion of new imaging technologies which have transformed what and how scientific knowledge is produced. I have long argued that all sciences are technologically-instrumentally embodied. That was the case with early modern science as it is with perhaps what now be called postmodern science. In the 17 th century, it was largely optics which made the observations of the then new sciences possible. Telescopes and microscopes transformed human vision at both macro and micro scales so that Galileo could see mountains on the Moon, the cycles of Venus, the satellites of Jupiter and sunspots. The Society of the Lynx, to which he also belonged, could, with the microscope, now see the seven labia of bees and the full anatomy of fleas never seen before, although it was Leeuwenhoek in the Netherlands who discovered sperm which led to an ultimate revolution in understanding reproduction. These new optics changed what and how humans could perceive, their vision was changed irreversibly.

My own interest has been focused upon imaging technologies in the sciences but I recognize that both in early modern and in contemporary times, the revolution in imaging technologies stretches far beyond science praxis. Indeed, one could make the case that new optical technologies actually preceded their uses in early modern science in that a wide variety of these technologies were used in the 16th century in art praxis-I refer to the camera obscura, camera lucida, framing devices and the like which were used to create the then new "Renaissance perspective". David Hockney's Secret Knowledge, a book on the use of the camera obscura in the Renaissance and Philip Steadman's Vermeer's Camera on Vermeer's use of one, showed the use of optics in art. And when we jump to the contemporary world the proliferation of screens from iPhones to iPads to laptops, TVs, cinema and on testify to an imaging-optical revolution far beyond the special practices of the sciences.

The primary point I wish to make in this paper relates to what would happen if the humanities and human sciences were to adapt the uses of scientific imaging 
technologies to their own practices. And in making this point about a material hermeneutics, I will develop a continuum of examples to illustrate just how radical such a movement could be. But first, let us look at a few examples from the history of the sciences. I have already hinted that the uses of early-and simple-optics are deeply implicated in the very invention of early modern science. It was the telescope which finally converted Galileo from his earlier standard acceptance of the Ptolemaic universe to a Copernican one. His actual telescope-mediated visions of the phases of Venus and the satellites of Jupiter, which he then advertised in his Starry Messenger essay, was the paradigm shift moment in his science. Leeuwenhoek similarly was moved to acknowledge the infinitesimal world through microscope use which eventually led to scientific biology.

Let us take a much longer perspective on this early instrumental revolution. It clearly is the case that virtually all ancient peoples had some elements of reliable knowledge of astronomy prior to early modernity. Calendars, the cycles of the Moon and Sun, solstices - and even records of the 23 days of visibility of the supernova 1054, today the Crab Nebula-were known all over the world. All of this was "eyeball" astronomy. With the first compound lens telescope, 1609 , astronomy became optical and with improved instruments continued to the 20th century. But such optical telescopy remained limited to the optical spectrum that which we, humans, could perceive of that narrow part of the electromagnetic spectrum. Our celestial universe remained small and limited-I admit as I studied this history, that I was shocked to learn that until 1923 there was thought to be only a single galaxy — the Milky Way-until Hubble recognized the Andromeda as a second galaxy. The first dramatic break with optical astronomy was the totally accidental invention of radio astronomy in the early 20th century. Starting with radio reception of static electricity in storms, learning to measure distance and direction, this new technological trajectory eventually led to the discovery of the (radio) background radiation of the universe itself and a Nobel Prize in 1978 for Robert Woodrow Wilson.

In all these cases what I today call material hermeneutics entails the interpretation of material culture and of the materiality of the humans themselves involved, whether as in early modern science, Renaissance art, or across the board in the disciplines today. As humanists know, hermeneutics has traditionally been textually and linguistically centered. As Ricœur pointed out, it gradually expanded from an interest in sacred texts earlier into the understanding-based humanities of the 19th century. What I am calling material hermeneutics is not 
textually nor linguistically based, but rather is a means of interpretation which allows meaning from things, of having "things speak". Regarding the practice of material hermeneutics, clearly I did not invent these. There are important disciplines which have since late modernity practiced such a hermeneutic: physical anthropology, archeology, the sciences of human origins and migrations and others. When one turns to human traces which precede writing and texts, perhaps even prior to speech, material artifacts, material culture must "speak".

Roughly, one may distinguish two stages of this material hermeneutics: the first is largely observational and categorical, entailing only simple instrumentation and measurement. The second is thoroughly instrumentally embedded and entails instruments which make both macro and micro features stand out. I will first cite a few familiar samples of the early form. Stone weapons and tools were used by humans long before there were texts or writing, and perhaps even before speech. I, myself, have an Acheulean hand axe, an ovaloid chipped stone tool of teardrop shape which style of artifact goes back roughly 1.800,000 years $\mathrm{BP}$ - well before the rise of Homo sapiens sapiens. Stone and bone tool kits are familiar and classified by shape, type of chipping, and other observable characteristics. Anthropologists and archeologists know well that such ancient artifacts survived to the disadvantage of most soft artifacts which could not withstand deterioration - until recently when wisps and traces may be picked up by the new instruments. Thus nets, textiles, non-ceramic items were overlooked or remained unfound. But there were exceptions. For example, "Venuses" as the crude female fertility figurines are dubbed, sometimes showed headdresses and woven suspenders, clearly evidence of fabric, depicted in stone. These go back in some cases to close to $40,000 \mathrm{BP}$.

And then there are the arguments about the peopling of the Americas, with still today a few hold-outs for 12,000 BP Clovis-Folsom tools as the earliest, in spite of this barrier now widely acknowledged to have been breached by minimally several thousands of years, perhaps even more than 10,000 years. But this evidence is already dependent upon the second revolution which includes the new, instrumental dating techniques (such as carbon-14, thermoluminescence and others). So allow me to drop what today must appear as "old" arguments and findings, and jump into our postmodern, in the sense of having transcended the modern limitations of material hermeneutics.

I will begin here a continuum of examples beginning within the ranges just covered when the human and social questions take place in a material context which has no writing, no texts, but for which knowledge may be produced, 
now through the mediation of instrumental technologies. My first example is Ötzi, the Iceman. Ötzi was a relatively well preserved mummy which had been buried in ice in the Italian Alps, and was discovered in 1991. First speculations were far short of the knowledge now evidenced-discoverers thought he might have been a skier or hiker perhaps a century or a little more ago. But, by applying today's science standards which utilize multiple dating processes such as previously mentioned, Ötzi could be dated quite close to 5,300 BP. He had been murdered- $\mathrm{x}$-rays revealed a stone arrowhead under his shoulder bone, later analysis showed it had severed a major artery. Blood remains on his hands revealed at least two DNA patterns other than his own, again produced by DNA analyzing instruments. He died in May, since the microscopic grains of the hop hornbeam tree, which sheds pollen only in May, showed up. His last meals included mountain goat and red deer meat and charcoal and einkorn wheat from bread. He had been ill three times during his final year, evidenced from fingernail deformations; had arthritis and rickets. Mass spectroscopy of tooth enamel-a favorite technique today-showed he had lived his life within 80 miles of his death site. I could go on and on, there are a number of books about Ötzi, but the point here is clear: these exquisite details about his life are produced through an instrumentally embodied analysis which is able to probe the most miniscule microscopic entities and identify these with precision. And in this case in the absence of any linguistic, textual or written evidence.

In the next two examples, I shall move into histories in which linguisticality and texts play an important role and I have chosen these examples which enhance some dialectic between the linguistic and the material styles of hermeneutics. My examples come from invasion-colonizations in which one side is literate and the other not. In the first case, the Viking invasions of England in the 8th to 11 th centuries, it is the invaded who are literate; the invaders the nonliterate. Historically, the case is highly complex because while the general history recognizes that Viking invasions extended from Scandinavia as far east as Russia, south to the Mediterranean, as well as west to the English isles, and to the North Atlantic with many of the invaded also functionally illiterate. But in England, the monks and the aristocracy were literate, and this gave them virtually the full advantage of narrative description of the invaders. Alcuin the scribe was assigned the history and of the early raid on Lindisfarne in 793, he writes, "Never before has such terror appeared in Britain as we have suffered from a pagan race. The heathens poured out the blood of saints around the altar and trampled the bodies of saints in the Temple of God, like dung in the streets." Other accounts describe the theft of golden sacred items and relics, arson and rape. These accounts are not 
necessarily untrue - the Vikings practiced seasonal raids early in their invasions and returned with riches to Scandinavia. But once one begins to balance the textual accounts with archeological analyses, a more complete picture emerges. The Vikings were on a major invasion and colonization trajectory. Most of the voyages to the west were to sparsely populated areas such as Iceland, Greenland, the North American coast and various island chains-England was the exception. By 884 , nearly a third of Britain had been colonized and the territory, which the Vikings ruled, called the Danelaw. Treaties with local kings, including Alfred the Great, had been signed and trade centers, farming and the like took on Viking characteristics, including parliamentary, monetary and legal practices deriving from Scandinavia, many of which became part of the English tradition. The material culture evidences this with Danegeld coinage, styles of armor and clothing, and longhouses. This "above ground" set of practices was matched by a fairly rapid assimilation by Vikings of Saxon burial practices "below ground." In short, in addition to seasonal raids early colonization later brought permanent changes to British practices. Assimilation practices also followed trading back to Scandinavia, with missionary Christianization and the introduction of medieval literacy going to the North. Vikings began to be literate in medieval times and, in short, invasion yielded more by way of hybridization than not. But the more complete picture of the era calls for both the linguistic and material hermeneutics to comprehend. Finally, I want to note in passing that the Vikings went through multiple layers of interpretations over time. From the heathen raiders of the monks' accounts to medieval converts three centuries later, to noble savages in the 18th and Arians of the 19th centuries there emerge very different narratives.

I shall begin my second invasion-colonization scenario with precisely the awareness of different historically layered narratives and this time turn to the Spanish conquistadors in the Americas during the 15th and 16th centuries. In this case, it is the invaders who were literate, and while there was an elite form of literacy in South America, codices and quipus were not to be found in North America. For personal reasons, I will look at Coronado's expedition to my home state of Kansas in 1541. My father grew a red beard in advance of the 400th anniversary of Francisco Vázquez de Coronado's arrival at the Smoky Hill River near my farm home with an entourage of some 45 soldiers and Indian guides. But this was also disturbing to me because Coronado, I was learning, appeared in Kansas fully 79 years before the official history taught in my school which claimed the first colonists were the triumphant English pilgrims arriving at Plymouth Rock in 1620. For you see, Spanish invasion-colonization, actually from Columbus's voyages of 1492-1503, followed by the Spanish invasions of 
South America and southern and western North America preceded both the Dutch and English of the northeast by more than a century. This history was suppressed by anglophilia. Later, in maturity, I learned from Charles Mann's magnificent book, 1491, what the Americas were like immediately before the European arrivals, and from Russell Shorto's The Island at the Center of the World: The Epic Story of Dutch Manhattan and the Forgotten Colony that Shaped America, had already shaped the multicultural and tolerant, even libertine world by the Dutch, which preceded the intolerance of the Pilgrims whose history remained dominant during my boyhood.

The earlier Spaniards, we all know, were obsessed with many things, including gold. Pizarro and Cortés had succeeded in discovering the vast gold artifacts of the South American indigenous civilizations which then stimulated dreams of more gold cities with gold hanging from trees. Ponce de León thought they would be found in Florida, and Coronado thought they were in Kansas as seven cities of Cibola, but which turned out to be the villages of the Quivira Indians. The textual record includes the comments that "Quivira is well settled. The land itself being very fat and black and being well watered by rivulets and springs and rivers. I found prunes like those of Spain and nuts and very good sweet grapes and mulberries." The writer notes that the people are nearly naked and quite tall with many men over six feet, much taller than the Spaniards. The villages were made of wicker framed houses with thatched grass covers in the shape of beehives. The villages often had some 200 of these houses. The Quivira combined farming with buffalo hunting, but they did not yet have horses which only settled the prairies later after going feral from those escaping the Spanish. Coronado stayed for 25 days, but then gave up on finding gold and began the return to Mexico. These observations on material culture match those of Mann's 1491 before European diseases decimated up to $95 \%$ of the population. Prior to decimation by disease, a material hermeneutic reveals that the indigenous diet was superior to that of the Spanish, more balanced with fruits and vegetables than the European taste for meats and stews. One of the contemporary instrumental practices entails mass spectroscopy, in which the identification of ions can determine diets through tooth enamel and bone analysis. Similarly, diseases such as arthritis and rickets may be detected and, throughout the burial grounds of the Spanish occupied areas of North America, the indigenous people showed less disease and better diets until succumbing to European introduced diseases. [As an aside, these same instrumental analyses have shown that our predecessors, the Neanderthals, had a weaning process of 1.2 years, a recent discovery on mass spectroscopy.] 
Before turning to a final example, I now will do a reflective pause turning to what I am calling a second scientific revolution of imaging and other analytic technologies which create the possibilities for a material hermeneutics. As indicated above, from early modern science on the investigations of the sciences have been technologically embodied. Led by optics, but abetted by other measurement and quantitative and imaging devices, the sciences have both gradually and sometimes revolutionarily described and interpreted our world. But what I am calling the second revolution begins in the 19th century. Photography became practical in 1839 , and practical spectroscopy began to transform astronomy by 1845 when spectroscopy was discovered to reveal chemical signatures of the stars. It revealed that the same segment of yellow and orange in the spectrum of the Sun was that of sodium and soon other parts of the spectrum showed that stars could be classified according to light gases—hydrogen and helium-to metals. X-rays were first produced in 1895. But most imaging processes which showed interiors, chemical make-up, subsurfaces were not invented until the 20th century-such as radio astronomy, imaging along the entire electromagnetic spectrum, ground penetrating radar, etc.

Secondly, these new instruments, as radical as the knowledge they produced, were primarily directed to the interests of the natural sciences. The instruments were expensive and often, early on, were relating to large funding such as associated with World War II, later the Cold War. The most sophisticated developments occurred with military, physics and astronomy and chemistry sciences, and the medical sciences. Everyone is familiar with the explosions of satellite imaging, submarine imaging, and by mid-20th century medical imaging such as CT X-rays, MRI, fMRI, PET scans and the like. Add electron microscopy, interferometry and dozens of other also usually large, very expensive new machines and you begin to understand the extent and economies of this revolution. The 1994 cancellation of the multi-billion dollar Supercollider was the largest and first cancellation of an instrument in this trajectory.

I make these points for two reasons: First, no humanities or social science funding, whether in Europe or America, could afford to simply apply these technologies to material hermeneutic uses! Not only does this fact cast a cloud over my recommendation for development, but it has been operational in a lack of progress over the roughly century of experimental practice. Whereas Ötzi, my first example, is clearly an exception-he has received massive instrumental treatment due to his popularity. And in recent times there have been more archeological examinations of Viking history than previously, in part because 
this three-century history has many events to investigate, but of the short-termed Spanish example, there has been little done.

There are exceptions, and these are often startling in their results, so by way of illustration I will pair some of these discoveries with the instruments used to indicate potential:

- Magnetometers and ground penetrating radar are devices which, used from flying airplanes, can map underground structures and reveal ancient humanbuilt artifacts. In discussions with Mexican archeologists I have been told about 8,600 buried pyramids in Central Mexico discovered through this process. Similarly, ancient temples in Southeast Asia, Iron Age monuments similar to Stonehenge in the UK have been mapped;

- Again, ground penetrating radar enhanced with laser and/or infra-red imaging can penetrate forested areas and many Mayan, Aztec and other Mesoamerican sites have been so mapped; the same process has been used to map ancient trails such as the Silk Road with branches previously unknown.

- Imaging processes have frequently been used to analyse paintings. X-rays, side-shadow lighting, and spectroscopic variations can show how many times and with what results painters have re-done their works. For example, Matisse's 'The Bathers' shows seven revisions over a thirty-year period. Many of Picasso's works show similar revisions.

- Chemical analyses, usually revealed again through mass spectroscopy can show forgeries, identify pigments by time and location identity. This same process with molecular and atomic identification has provided evidence for human migration and trade practices, a favorite of mine being a 3,000-mile eastern to western Pacific obsidian trade going back 3000 years-obsidian from a volcano transported backwards to Indonesia has been reported.

- And, for gratis, since many of you will have watched the capture of the Boston bomber while he hid in a boat in a backyard, there is thermal imaging. Every movement of the bomber was clearly imaged from a helicopter and the same imaging can show heat shadows of everything from vehicles to humans through night vision optics.

These illustrations, while often isolated and not systematic, are highly indicative of the potential of material hermeneutics to transform our understanding of human activity as a humanities and social science knowledge production. Minimally, my claim is that the addition of such a hermeneutic to these disciplines would radically expand and change our narratives. I now want to conclude by turning to a contemporary and, admittedly, complex issue which can show just how 
material hermeneutics plays a role here and now. My example relates to the debate about anthropogenic issues in climate change.

This case study relates to climate change, human beliefs, and the role of anthropogenic factors stimulating climate change. (The occasion in Gröningen was excellent for such an analysis since it took place in Europe rather than in the United States, which is my cultural context for the example). I shall here mix linguistic and textual dimensions with those of a material hermeneutic, but with the aim of showing the importance of the latter for the debate. Here is the context:

- The issue of climate change related to anthropogenic causal factors is a highly political and ideological issue in the US. Conservatives, including a vast majority of Republicans, deny minimally that there are any anthropogenic causes involved in climate change and a significant number of these groups deny there is evidence for climate change itself or that it is a hoax.

- Fifty per cent of Americans also believe that there is significant doubt among scientists concerning anthropogenic causes of climate change. However, in recent weeks, science magazines have been reporting results from seven separate science polls concerning attitudes amongst scientists on climate change and anthropogenic origins: all seven of these analyses show that 95-97\% of scientists both affirm climate change and anthropogenic origin factors. As early as 1991, James Hansen ${ }^{2}$ claimed that $24 \%$ of global warming could be attributed to anthropogenic factors.

The issue of global warming, climate change and anthropogenic factors is an issue which largely came to concern in the 20th century, at a time when the sciences also were undergoing massive change. Big science, a term coined by Derek de Solla Price in $1963^{3}$, has characterized physics since the Manhattan project, chemistry earlier in manufacturing and agricultural areas, and biology since the genome project, but the complexity of big science also relates to the shift in tools, such as simulations and computer modeling which is used extensively in systems and climate sciences. These tools are more relevant to more contemporary sciences and are used by mostly younger scientists-including the leaders in the climate sciences. In order to sharpen the issues under debate, I shall follow the case study practices of STS or science-technology studies of recent decades. Here leading questions include: who are the principals? And who benefits?

2 I personally know James Hansen well and was aware of his Congressional appearance in 1988 which made us aware of global warming.

3 However, see Weinberg, 1961 (Editor's note). 
To begin, sites where the debates are highly focused include the courts. Judges, as players, are gatekeepers in the following significant way: they may decide what is admissible as expert scientific testimony. Until quite recently the standard was known as the Frye Standard which holds that what is "generally acceptable to science" practice is sufficient to allow testimony. However, in a series of Supreme Court decisions from 1993 to 1999, the Frye Standard was superseded by what is known as the Daubert Standard. This standard is stricter and relates to a more contemporary set of standards. I hold that expert witness must follow testability, verification and falsification practices and implicitly recognizes the probabilistic standards for certainty of $95-97 \%$ probability. (Bayesian and Popperian principles can be seen at work here.) Many of the cases today apply to climate issues and also to biotechnology issues-in 1993, the case involved Monsanto, this year it involves the issue of whether biotechnological genes are patentable. How, then, does this relate to my issue in which the US public believes that there is significant scientific disagreement about anthropogenic factors and the clear science consensus that there is not such scientific disagreement?

Who are the principals?

- In 2010, historians Naomi Oreskes and Eric Conway published a book, Merchants of Doubt, which showed that a small group of scientists (all physicists, mostly from the atom bomb and subsequent Cold War times) who were media savvy, highly organized and corporately connected, first began campaigns to deny nicotine was carcinogenic, denial of the ozone hole and later the same group began climate change denials. Early funding came from the tobacco industry, later funding from energy corporations. It is significant that it was this same small group who led both highly publicized denial campaigns.

- Funding, organization and publicity campaigns shifted in the 80 s to The Heartland Institute, active primarily in the Midwest and South with contributors from what could be called the elite of the most conservative support groups. These included the Koch brothers, the Walton family (Walmart), oil and gas, big pharma, tobacco corporations. From 2010 to 2012 a series of highly publicized (and subsidized) anti-climate conferences were held. I, myself, took the time to review lists of presenters and discovered that (a) most were retired scientists, (b) virtually none were in the climate or earth sciences, and (c) many were identifiable from the Merchants of Doubt book.

- Media, too, play strong roles in the propaganda of denial. In the US, the prime player is the News Corporation, i.e., Fox News and Rupert Murdoch. The 
strategy used is the claim that Fox News is "balanced" news which translates into having whatever is considered the dominant view be contrasted with its opposite. Thus the dominant scientific view that there is global warming and climate change must be contrasted with denial and skepticism. What the balance does not reveal is the disparity between the views with $95-97 \%$ on one side and $3-5 \%$ on the other. Here an extreme minority view is amplified, but also any moderate views are excluded. This result has colored much of the current political atmosphere in today's US environment.

Who benefits?

- Here the answers are obvious. In the early days of the tobacco controversy, the industries benefited through lack of regulation or payment of damages for health problems caused and the same applies to the industries of today's controversies. Note, however, that eventually the tobacco industry did lose and its costs were considerable. The same does not yet apply to the fossil fuel or carbon producing industries of today.

It is now time to return to material hermeneutics. With this issue I am contending that the dominant evidence which has led to the scientific consensus of global warming, climate change and anthropogenic factors comes from instrument mediated and produced knowledge. I will but briefly cite a few of the most obvious results as related to the instruments used.

- As noted above, computer-driven complexity analyses in the form of simulations and modeling have come into prominent use only since the mid-20th century. While not perfect, the multiplication of variant models often yields ever more precise predictive patterns. Not immediately related to my issue here, it was amusing to me to find that some 500 simulations of retirement strategies were used by my retirement designers to assure a $95 \%$ plus outcome. By using multivariate models, the high probabilities needed for scientific evidence standards is increasingly used.

- One factor which is necessary to show how drastic earth warming is calls for long chronological measurements. Antarctic gas isotope records now show a precise record back at least 400,000 BP.

- Glacial, Greenland, and Arctic melting factors have become very obvious in recent, late 19th to 21 st century, periods.

- Greenhouse gases, particularly those related to the ozone hole, are carefully measured today and the restriction of some of these has already shown responsiveness and partial reversal is possible. 
- Ocean level measurements which entail ocean buoys, satellite gravity measurements, shore measurements, again multiple variant instruments, have shown year-to-year ocean rise changes.

- Specifically regarding anthropogenic factors, the identification of fluorocarbons from leaded refrigeration gases, identifiable sources of carbon products, including large soot particles from outdoor cooking fires in the Third World, lead-related products in the atmosphere beginning in Roman times but accelerating since the industrial revolution all are clearly of anthropogenic origin.

These and many more go into the evidence base which stimulates the agreed upon 95-97\% consensus amongst scientists concerning climate change. Unfortunately, such a material hermeneutic has not captured the public consensus to the same degree.

My final example may have seemed odd because I chose a current science-politics issue rather than something more directly within the context of humanities and social science. My theme has been to introduce a material hermeneutics to humanistic and social science analyses. My last example is, if anything, too complex. On the surface what might seem to be the case is that the consensus within the scientific community-the 95-97\% agreement about climate change including anthropogenic factors-is simply the result of this community taking seriously the evidence of an instrument mediated production of scientific knowledge, in contrast to a public which seems more swayed by the political and rhetorical media and linguistic context. This could itself produce an oversimplification: the scientific community, accepting the results of an instrument-mediated knowledge which contradicts the media and rhetorical conversation is simply more critical and rational than the public. Were this not to be the case, we would be back to Plato's equally simplistic Republic. Here is the catch. The rhetoric which captures the public is also instrumentally mediated. Television news, cable, social media in addition to the older newspapers, magazines are also instrumental media. These are not, however, mediating what I have been calling a material hermeneutic.

The instrumental mediations regarding global warming are readings and measurements of global activities, melting glaciers, rising oceans, warming seas. Yes, these are then reported but the probes of the "things themselves" are what allow the things to "speak." As the book, Merchants of Doubt points out, the tobacco and later climate skeptics are not pointing primarily to either laboratory or instrumental results so much as raising doubts about the interpretations of such results. So, in one sense, the new questions are not only "who are the 
principals?" and "who benefits?" but "what is speaking?" and "what is said?" In both cases the interpretation calls for a critical take. So, here I may return to the beginning because Ricœur once again becomes relevant. He called for a critical hermeneutics, utilizing both a "hermeneutics of doubt" and a "hermeneutics of belief". Thus while I am calling for a listening to materiality, I also agree with Ricœur that interpretive activity must be critical in the best philosophical sense.

\section{References}

Alcuin (793), Letter of Alcuin to Ethelred, king of Northumbria (793, after 8 June). Retrieved from http://east-midlands-archaeology.blogspot.com/2014/10/alcuinsletter-to-ethelred.html [accessed Sept 2020]

Galilei, G. (1610), Sidereus, nuncius: magna, longeque admirabilia spectacula pandens, suspiciendaq[ue] proponens vnicuiq[ue], praesertim vero philosophis, atq[ue] astronomis [Starry Messenger], Prostat Francof.: In Paltheniano. https://doi.org/10.5479/sil.95438.39088015628597

Hockney, D. (2006), Secret Knowledge: Rediscovering the Lost Techniques of the Old Masters, London: Thames \& Hudson.

Ihde, D. (1971), Hermeneutic Phenomenology: The Philosophy of Paul Ricour, Evanston, IL: Northwestern University Press.

Ihde, D. (1990), Technology and the Lifeworld: From Garden to Earth, Bloomington, IN: Indiana University Press.

Ihde, D. (1998), Expanding Hermeneutics: Visualism in Science, Evanston, IL: Northwestern University Press

Mann, C. C. (2006), 1491: New Revelations of the Americas Before Columbus, New York: Vintage Books.

Oreskes, N. \& Conway, E. E. (2010), Merchants of Doubt: How a Handful of Scientists Obscured the Truth on Issues from Tobacco Smoke to Global Warming, London: Bloomsbury.

Richardson, W. J. (1963), Heidegger: Through Phenomenology to Thought, Dordrecht: Springer.

Shorto, R. (2005), The Island at the Center of the World: The Epic Story of Dutch Manhattan and the Forgotten Colony that Shaped America, New York: Vintage Books.

Solla Price, D. de (1963), Little Science, Big Science, New York: Columbia University Press. https://doi.org/10.7312/pric91844

Weinberg, A. (1961), 'Impact of large scale science on the United States,' Science, vol. 134, no. 3473 (21 July 1961), pp. 161-164.

https://doi.org/10.1126/science.134.3473.161 
Winship, G. P. (1922), The Journey of Coronado, 1540-1542: From the City of Mexico to the Grand Can[y]on of Colorado and the Buffalo Planes of Texas, Kansas and Nebraska. As told by himself and his followers, New York: Allerton Book Co.

Don Ihde is a distinguished professor at the Stony Brook University, New York. His interests lay in philosophy of science and technology, interculturalism and pluralism in perception, in which fields he has published over 20 books. At least since his Postphenomenology, Essays in the Postmodern Context (1993), he has been known as the founder of postphenomenology, a modified phenomenology and pragmatism focused upon analysing technologies. His focal research-for now 40-plus years-has been imaging technologies with a development of 'material sensitivity' in relation to human experience and skill development highly influenced by Maurice Merleau-Ponty and Hubert Dreyfus. His 1998 Expanding Hermeneutics: Visualism in Science looked into the human perceptual bodily relations to science practice and Material Hermeneutics follows these consequences. He is proposing to destroy the duality of the Diltheyan Divide and develop a singular hermeneutic centered style of analysis for both natural and human sciences. 